Enrico Morano

Some Codicological Remarks on the Corpus

of the Berlin Turfan Manichaean Sogdian Manuscripts

in Manichaean Script: among Books, Glossaries, Letters, Booklets, Bilingual and Trilingual Texts, Normal, Bold and Cursive Script

Abstract: The paper gives a survey of the codicological variety of the Sogdian manuscripts in Manichaean script of the Berlin Turfan Collection. Book formats, paper/silk/leather type, re-used paper, scripts and plurilingualism will be examined and commented upon.

Key words: Codicology and palaeography, Middle Iranian languages, Sogdian language, Manichaean texts and literature, Manichaean script, Multilingualism, Writing materials on the Silk Road.

The Berlin Turfan Collection of manuscripts from Central Asia includes, amongst a great variety of texts and languages, about 590 fragments of Sogdian texts written in Manichaean script. They were first catalogued, together with the Middle Persian and Parthian fragments, in BOYCE 1960. An updated catalogue of all the manuscripts containing Sogdian texts in Manichaean script is found in MORANO 2007. After more than a century since their discovery, still more than one third remain unpublished. The aim of this paper is to give a survey of the codicological variety of these manuscripts. ${ }^{1}$

(C) Morano, Enrico Independent scholar, Turin/Berlin ec.morano@gmail.com

${ }^{1}$ I wish to thank the Berlin-Brandenburgische Akademie der Wissenschaften and the Staatsbibliothek zu Berlin-Preußischer Kulturbesitz for allowing me to study and publish these texts from their collection. I am deeply indebted also to all the staff of the Akademienvorhaben 'Turfanforschung', Berlin for help and for making me at home in the Institute. Last but not least, my warmest thanks to the curator of the Museum für Asiatische Kunst, Lilla Russel-Smith, for allowing me to print the photographs of the manuscripts kept in the museum. 


\section{A Formats}

\section{A.I. Book}

A.I.1 Bound book

Manichäisches Bet- und Beichtbuch (MIK III 53), usually abbreviated BBB [pl. 1]

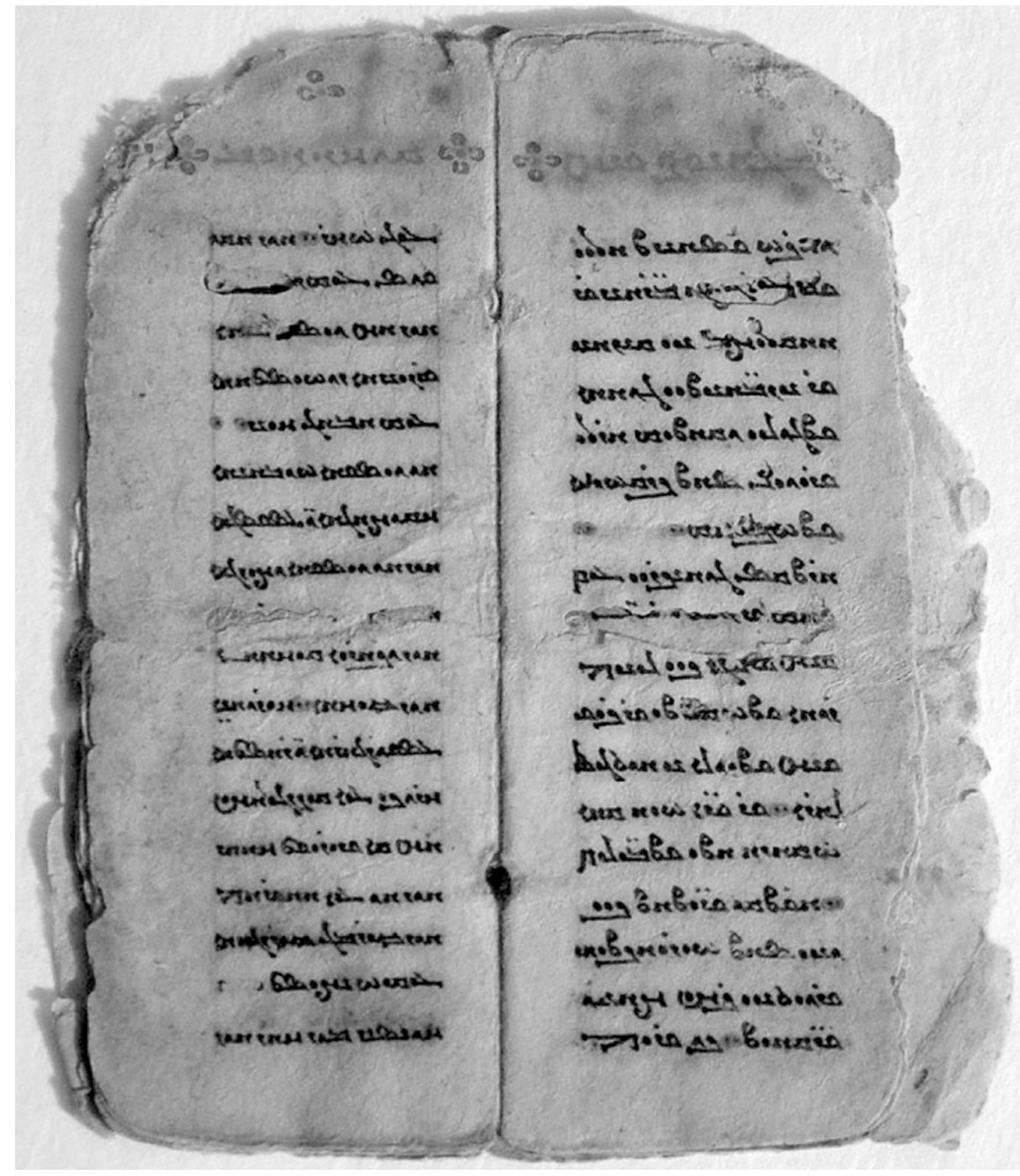

Pl. 1.

The so called Manichäisches Bet- und Beichtbuch (MIK III 53)

Photo: courtesy of the Museum für Asiatische Kunst, Berlin. 
Among the manuscripts brought back to Berlin from Central Asia by the German expeditions this manuscript is unique as it is the only bound book we have. This manuscript's technique of binding the individual bifolios one to another within the quire is fully described in GULÁCSI 2005, 64. ${ }^{2}$ At some stage after its production and before its discovery it had been pulled apart and wrongly rebound. ${ }^{3}$ Müller published a small section of it in his pioneering book Handschriften Reste: ${ }^{4}$ although Middle Persian could be discerned in much of the writing, there was also a hitherto unknown language there, for which Andreas proposed to call Sogdian. ${ }^{5}$ The book comprises a liturgy in Middle Persian and Parthian, but its second part is a confessional text in Sogdian, the vernacular of the worshippers of the Turfan region. The entire book is glassed and only one double page is visible to the beholder (see pl. 1). The sheets were last removed when the book was photographed for publication in WEBER 2000. These photographs enlarge the original and provide a good reading of the single pages. The photographs number the pages in the order in which they were found, which was not the correct order established by Henning. It is unfortunate that the photos are not in colour, since the different inks used in the headlines of each page ${ }^{6}$ are important in determining the correct order of the sheets. Henning explains this and other evidence for his reconstruction of the book in the introduction to his edition. Henning's epoch-making edition ${ }^{7}$ was, and still is, a basic starting point for Sogdian studies. Each bifolio measures approximately $8.8 \times 6.3 \mathrm{~cm}$.

\section{A.I.2 Single bifolio from a "monographic" book}

\section{M178 = MIK III 4990}

Publ. HenNing 1948 [photo: WeBer 2000 pl. 149-150, here pl. 2 and 3]

\footnotetext{
${ }^{2}$ For some aspects of the organisation of Manichaean books in Central Asia see also DURKIN-MEISTERERNST 2008.

3 "The thread holding together the 12 surviving bifolia of the BBB [...] is not the thread used in the original codex. Although it is a historical thread discovered together with the manuscript, the bifolia that it held together were found stacked in a false sequence. Also, it appears too crude compared to the delicacy of the book", GULÁCSI 2005, 64.

${ }_{5}^{4}$ MÜLLER 1904, 99-100. It contains BBB 650-664.

5 Apud Müller 1908: 3, note 3.

${ }^{6}$ See Henning 1936, 4-5, where all the colours of the inks used in writing the headlines are meticulously described. See below ad section $\mathbf{E}$.

${ }^{7}$ HeNNING 1936.
} 


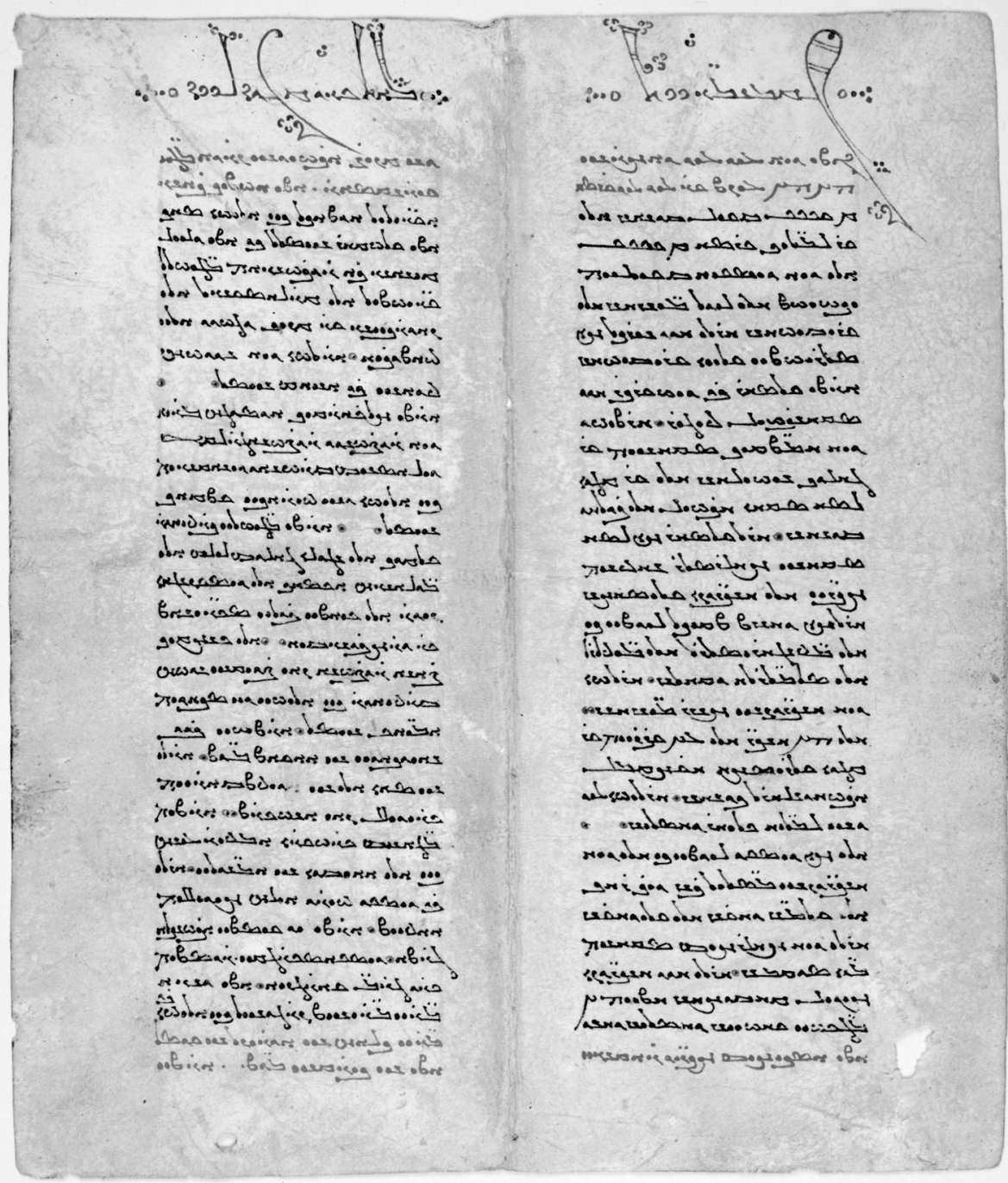

P1. 2.

M178=MIK III 4990

Photo: courtesy of the Museum für Asiatische Kunst, Berlin. 


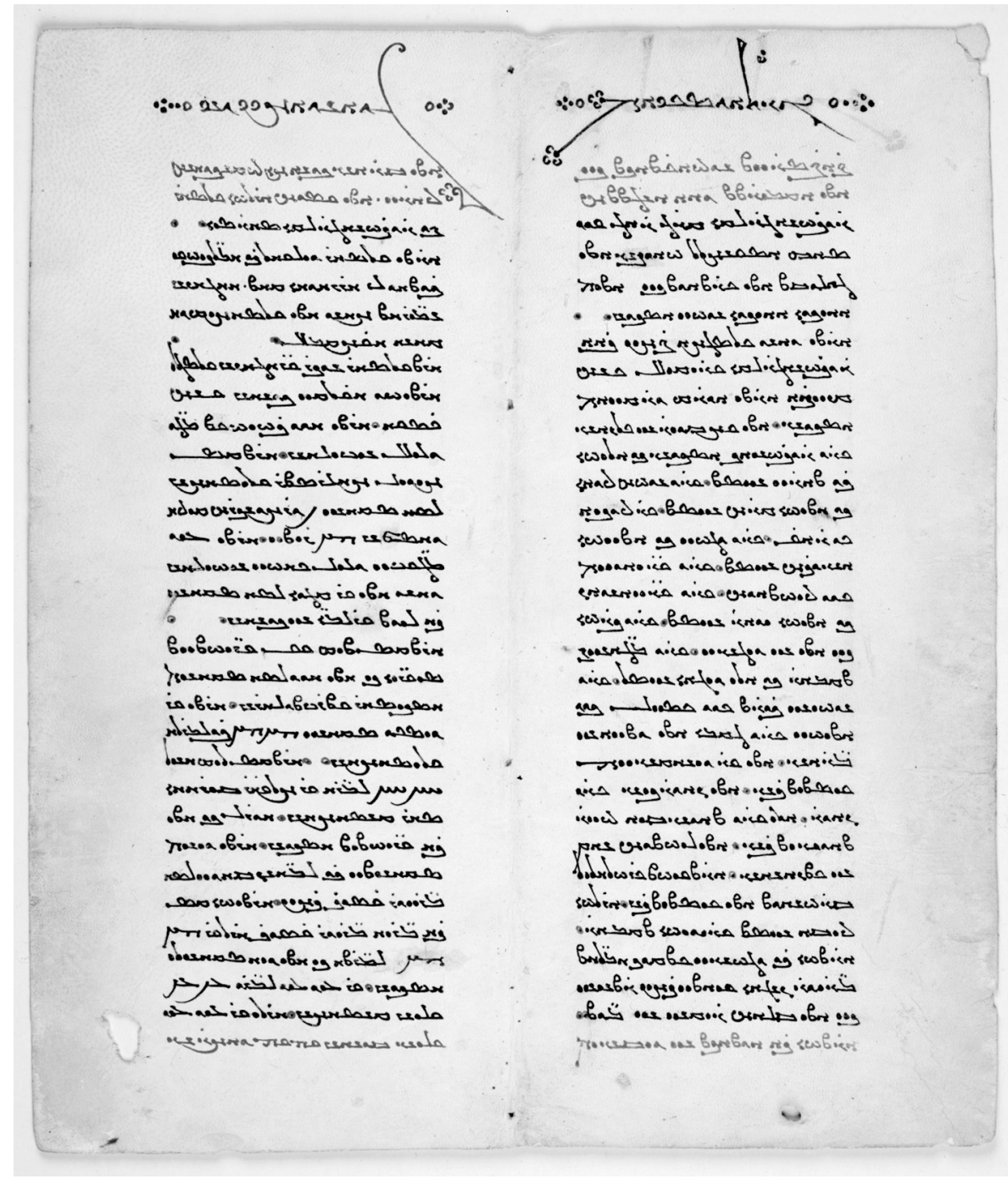

Pl. 3.

M178=MIK III 4990

Photo: courtesy of the Museum für Asiatische Kunst, Berlin. 
This Sogdian bifolio, written in outstanding calligraphy in Manichaean script on leather ${ }^{8}$ is not only the best preserved Manichaean text ever found, ${ }^{9}$ but it is also one of the most elaborate accounts of the Manichaean cosmogony. Müller published some excerpts in his pioneering work of $1904,{ }^{10}$ when Sogdian was still not recognized, ${ }^{11}$ and a proper edition of this important text had to wait some 44 years, until Henning fully published it. ${ }^{12}$ The bifolio measures $23.5 \times 20.5 \mathrm{~cm}$.

A.I.3 Single bifolio from a collective book (sometimes containing texts in different languages)

M528 a and b (one language) [pl. 4]

Two fragments ( $a$ and $b$ ) probably forming the lower part of a double sheet (BOYCE 1960, 37). a: confessional; b: from the story of the protoplasts, publ. BBB e, 48 [photo: WEBER 2000, pl. 75]. Fr. a: $7.7 \times 10.5$ cm; fr. b: $7.5 \times 10.5 \mathrm{~cm}$.

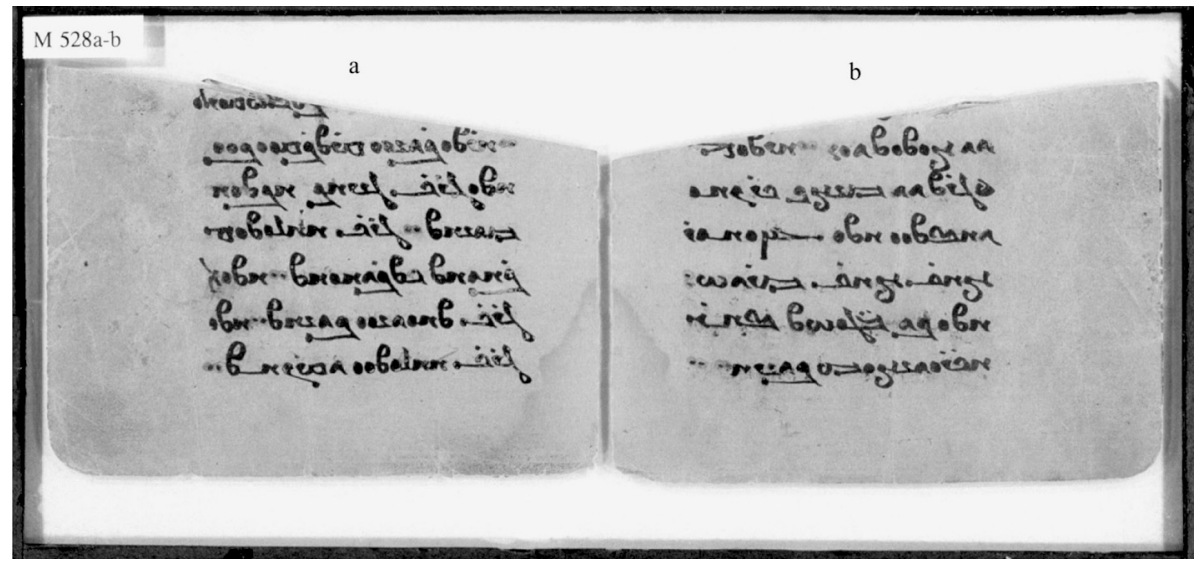

P1. 4.

M528 a and b

Depositum der Berlin-Brandenburgischen Akademie der Wissenschaften in der Staatsbibliothek zu Berlin - Preußischer Kulturbesitz, Orientabteilung.

Photo: Fotostelle der Staatsbibliothek zu Berlin.

\footnotetext{
${ }^{8}$ See Boyce 1960, 143. Additional information in Morano 2007, 244.

${ }^{9}$ See Müller 1904, 96: "Ein Doppelblatt aus weißem, dünnen Leder, ein kalligraphisches Meisterwerk...”.

${ }^{10}$ MÜLler 1904, 96-98.

${ }^{11}$ MÜLLER called the language of this text simply "Dialekt".

12 "When one views the development of Sogdian studies, founded as they are on this first publication, one is surprised at finding that the fragment has remained in limbo these many years", HENNING 1948, 307.
} 
M280 (two languages) [pl. 5]

Double sheet. /I/ Pth., Hymns (publ. RECK 2004, 95), /II/ Sogd., Hymn. [same manuscript as M137 and M5264, containing the same kind of texts] (publ. MORANO 2017b: 176ff.); [photo: RECK 2004, Taf. I; MORANO 2017b: 183-184, figs 5-6, in colour]. $8 \times 3.5 \mathrm{~cm}$.

This double sheet contains, like M137 and M5264 (only the Sogdian page), from the same manuscript, opening verses of Parthian Monday hymns on one page and Sogdian hymns on the other.

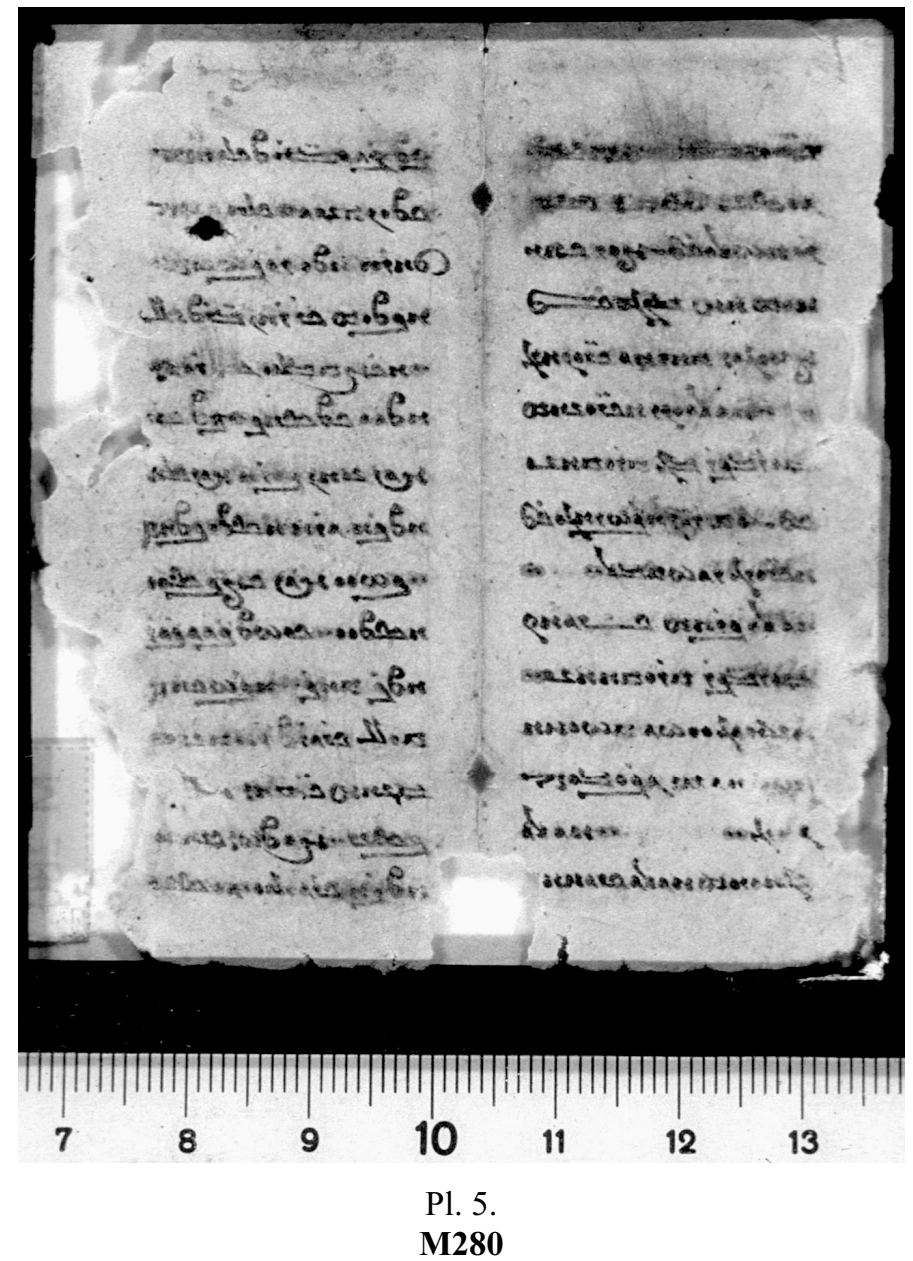

Depositum der Berlin-Brandenburgischen Akademie der Wissenschaften in der Staatsbibliothek zu Berlin - Preußischer Kulturbesitz, Orientabteilung. Photo: Fotostelle der Staatsbibliothek zu Berlin. 
A.I.4 Single page from books (mostly fragmentary)

M760 [pl. 6]

Sogd., Uyg. Ruled margins. ${ }^{13}$ Tale. Publ. MorANO 2009, 185-187. 16.4× $11.8 \mathrm{~cm}$.

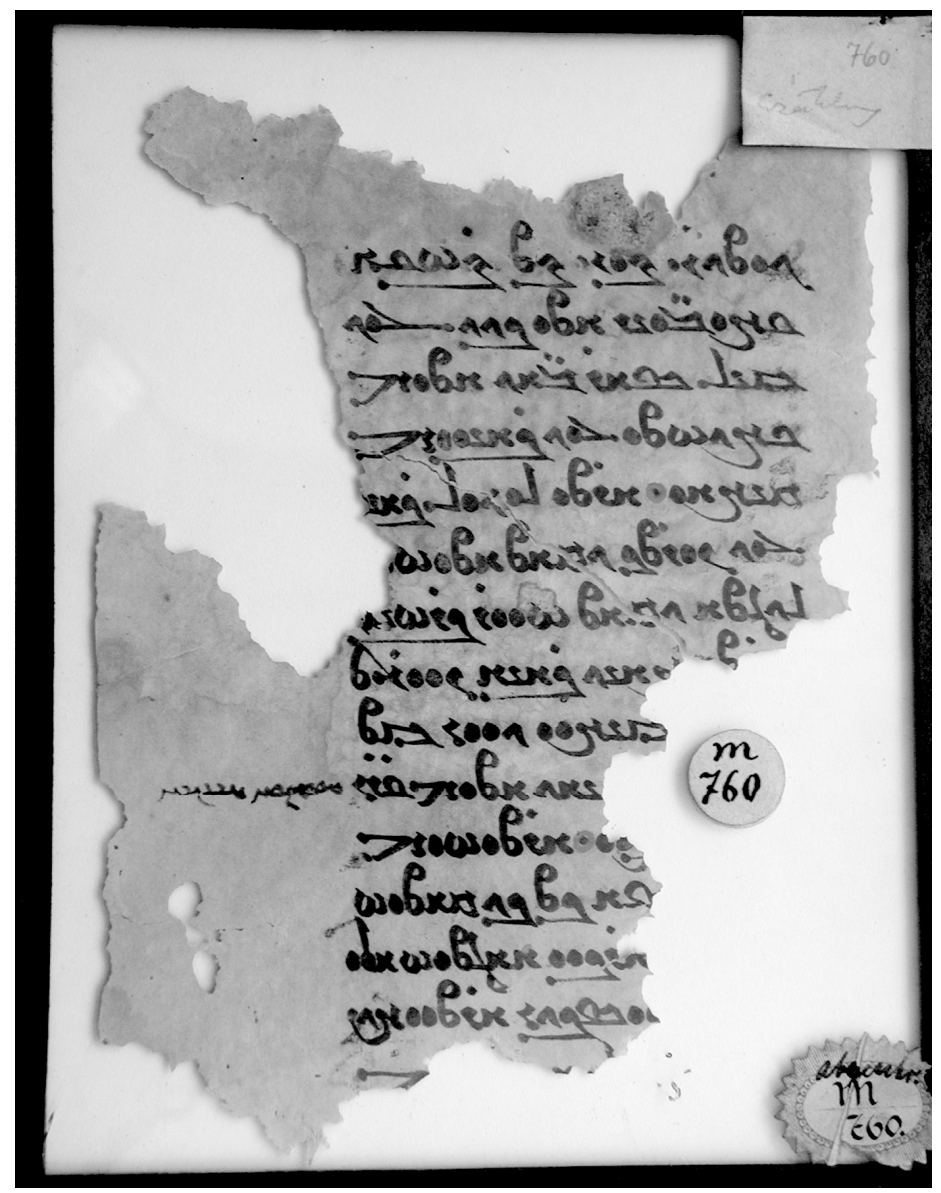

Pl. 6.

$\mathbf{M 7 6 0 / R / ~}$

Depositum der Berlin-Brandenburgischen Akademie der Wissenschaften in der Staatsbibliothek zu Berlin - Preußischer Kulturbesitz, Orientabteilung. Photo: Fotostelle der Staatsbibliothek zu Berlin.

${ }^{13}$ Very often margins are ruled by vertical tiny red lines. In some cases they form, with horizontal red lines, a grid which encompasses the text. 
This is an almost entire page from a book of tales, of which several other fragments are in the Berlin collection. ${ }^{14}$ In some places Uygur glosses, or rather translations of Sogdian words of the text, either on margin or between lines, are present: a unique feature among the Sogdian Manichaean texts, as far as we know. ${ }^{15}$ See also below B.I.1.

\section{A.II. Large folio (often re-used)}

A.II.1 used for letters (verso blank ${ }^{16}$ or with Uygur text)

\section{M112+M146a+M336c [pl. 7]}

/R/ Sogd.; /V/ Uyg. Joins M146a and M336c. Letter, publ. SUNDERMANN 1980, 305-06, I (14-42). [Photo: WeBER 2000, pl. 24]. Re-publ. SUNDERMANN 2008, 405ff. /V/ see WILKENS 2000, 66f., N. 41. 27×26 cm.

In the Berlin Collection there are at least three examples of large sheets of fine paper used for private letters. The verso side is in some cases left blank, in some others re-used by the Uygurs.

\footnotetext{
${ }^{14}$ See Morano 2009, 181.

${ }^{15}$ The book could have been belonged to a schoolboy, or perhaps to a learned man, who annotated some Sogdian words with the corresponding Uygur words.

${ }^{16}$ Some fragments have a blank verso. This could indicate, if found on pages from a codex, that a page was left blank on purpose, for instance at the end of a section, or to leave room for a painting or illumination, see GULÁCSI 2005, 96 and 195. In case of letters written on very large thin paper, like the one shown here, the text of the letter was written only on one side, and the blank side was re-used later by the Uygurs. Of the three Manichaean letters (two published by SUNDERMANN 1980 and 2008) only the third one, published by BENKATO 2016, 200ff., has the verso still blank. For some reason all examples of letters in cursive script we have are written on one side only, the other side being left blank, or re-used by others, see the table in BeNKATO 2016, 199.
} 


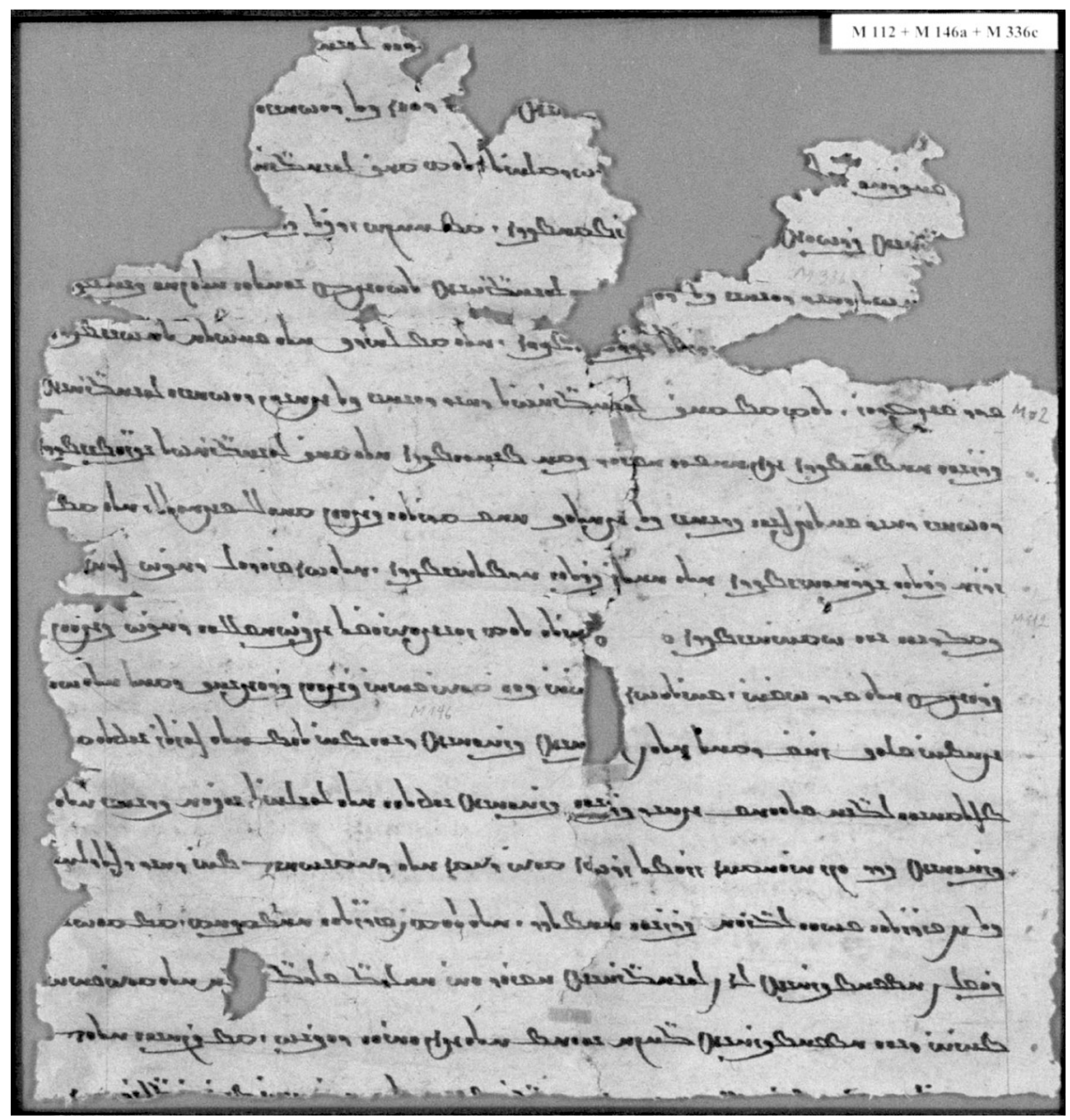

\section{Pl. 7.}

\section{M112+M146a+M336c}

Depositum der Berlin-Brandenburgischen Akademie der Wissenschaften in der Staatsbibliothek zu Berlin — Preußischer Kulturbesitz, Orientabteilung. Photo: Fotostelle der Staatsbibliothek zu Berlin. 


\section{A.III. Page cut vertically from a Chinese scroll}

A.III.1 used for several texts, such as letters, tales, glossaries, etc.

M309b [pl. 8]

/R/ Sogd.; /V/ Chin. /R/: tale.

Chinese Buddhist texts (VI-X centuries AD) were written on a scroll measuring ca. $26 \mathrm{~cm}$ (in height). The fragment M309b measures ca. $12 \mathrm{~cm}$ and one may assume another ca. $14 \mathrm{~cm}$ for the gap. On the other hand, many Manichaean Sogdian texts were written on just half the Chinese scroll (that is, the scrolls were cut into half vertically in order to write Manichaean texts). In this case they used the blank side to write a tale. Published in MORANO 2017a.

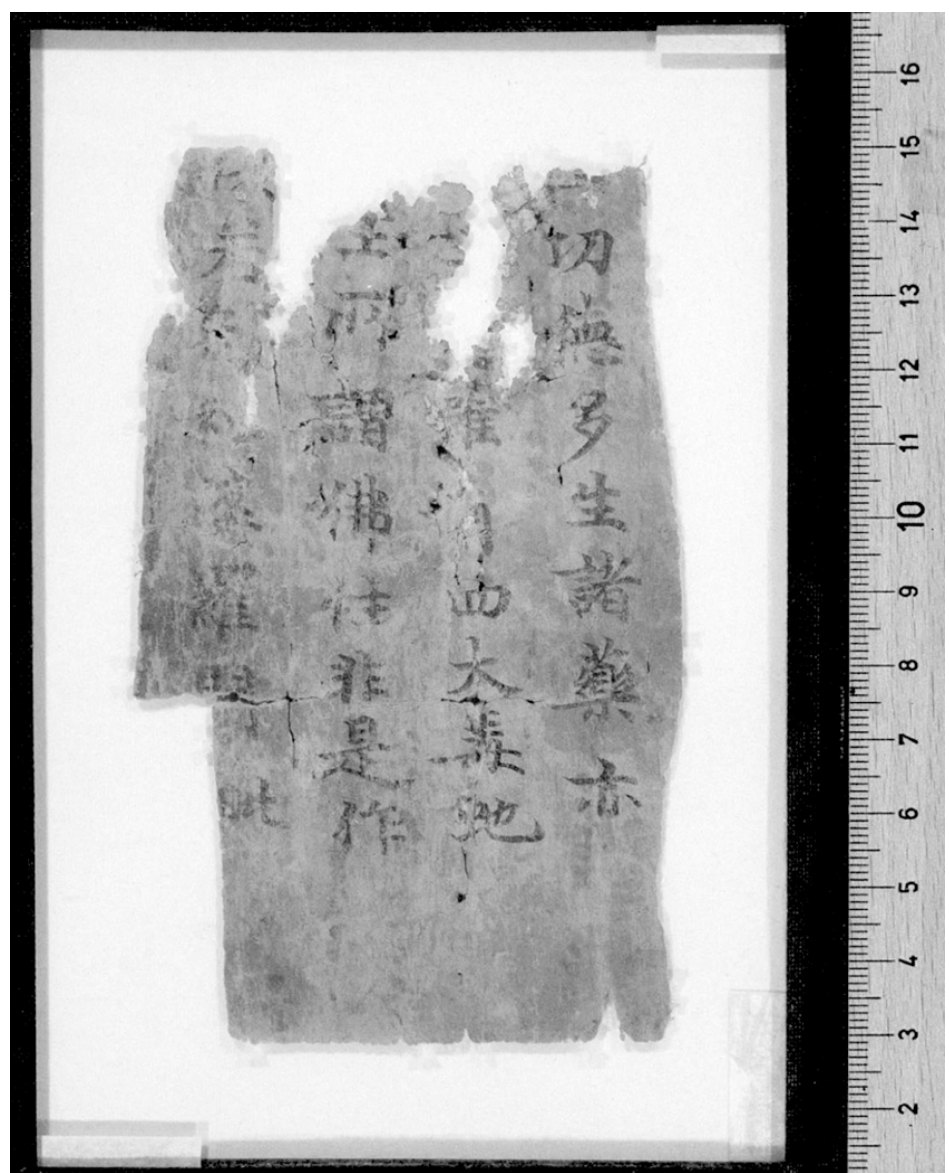




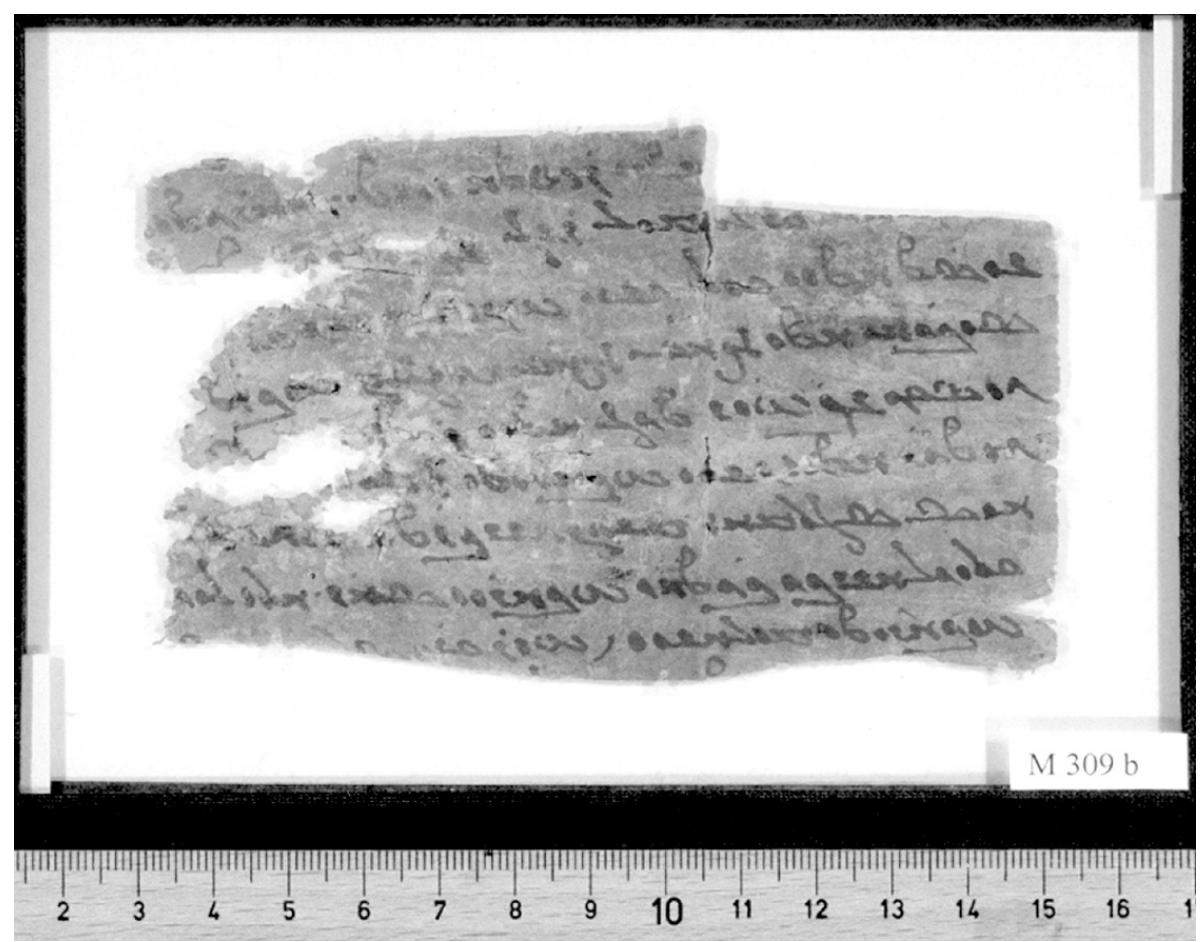

P1. 8.

M309b

Depositum der Berlin-Brandenburgischen Akademie der Wissenschaften in der Staatsbibliothek zu Berlin — Preußischer Kulturbesitz, Orientabteilung. Photo: Fotostelle der Staatsbibliothek zu Berlin.

\section{M111+M725/I/ [pl. 9]}

/I/ Pe., Pth., MSogd.; /II/ Turk. Joins M725. Ruled margins. Pe./Pth. and Sogd. glossary. Publ. HENNING 1940, 21 [photo: WeBER 2000, pl. 22-23].

"The page was formed by gumming together the inscribed sides of two pieces of paper which had been cut from a Chinese roll. Slightly damaged.

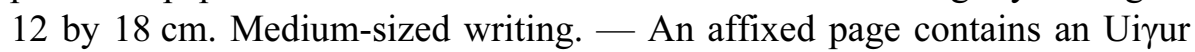
text of unknown contents". ${ }^{17}$ /II/ see WILKENS 2000, 303f., N. 339: "Lobpreis auf einem Herrscher, Erwähnung eines Gewissen M(a)r Šad Išu. $\mathrm{Ab} / \mathrm{V} / 13$ / Beginn eines weiteren Hymnus".

\footnotetext{
${ }^{17}$ HenNING 1940: 15 frgm. b.
} 


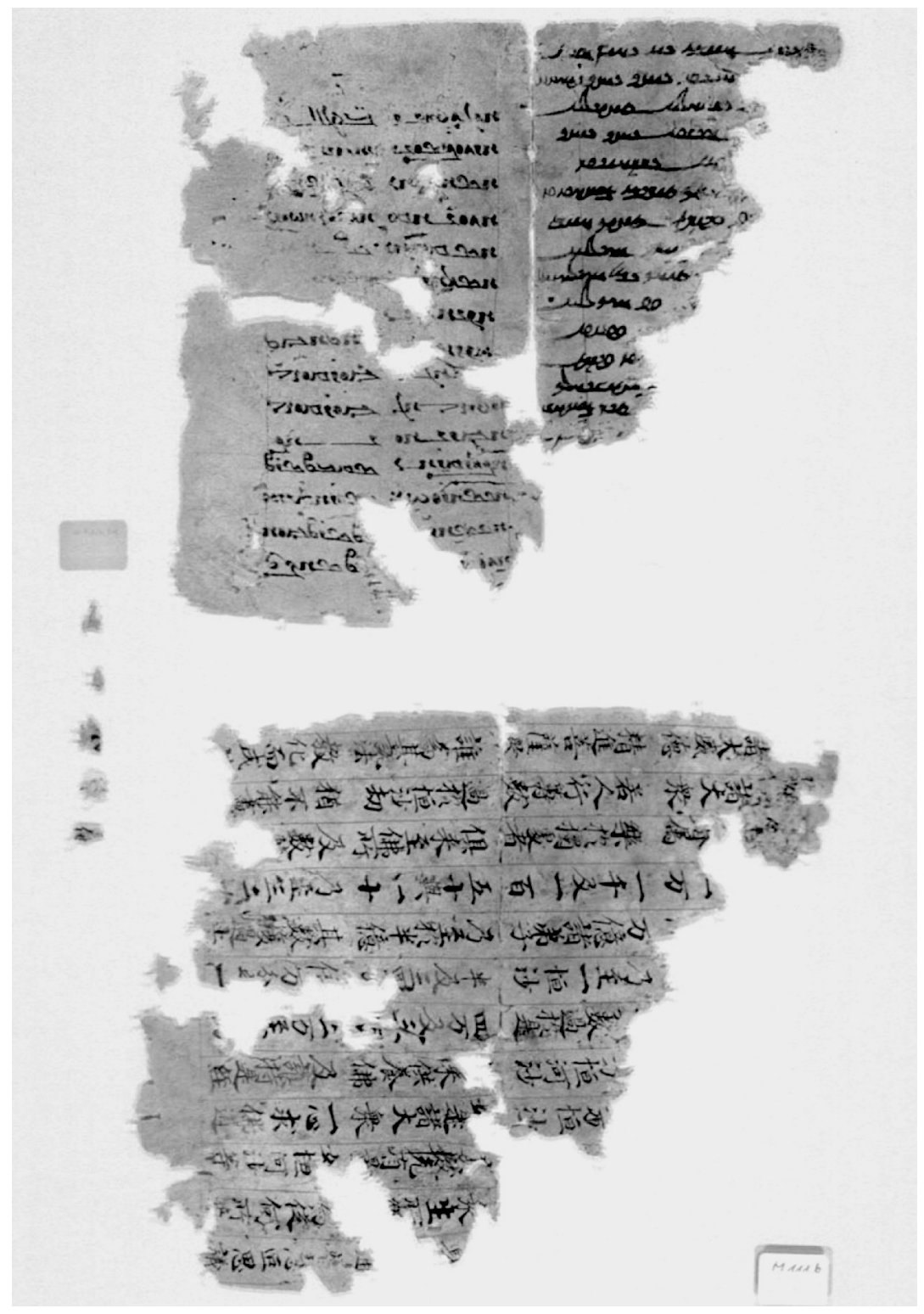

Pl. 9.

M111+M725/I/

Depositum der Berlin-Brandenburgischen Akademie der Wissenschaften in der Staatsbibliothek zu Berlin — Preußischer Kulturbesitz, Orientabteilung. Photo: Fotostelle der Staatsbibliothek zu Berlin. 
A.III.2 Almost all the Sogdian manuscripts in Manichaean script are pages, or fragments from pages, of codices. Only in one case (M7420) we have a small scroll, cut from a Chinese scroll, containing an abstract of the parable of the Religion and the Ocean written vertically on the verso.

M7420 [pl. 9bis]

/R/ MSogd., /V/ Chin., MSogd. (1 line written in margin). Abbreviated version of Azand-nāme. Publ. SUNDERMANN 1985, 36 [ph. XXI], re-edited BENKATO 2017, 112-114. 22, × $5.6 \mathrm{~cm}$.
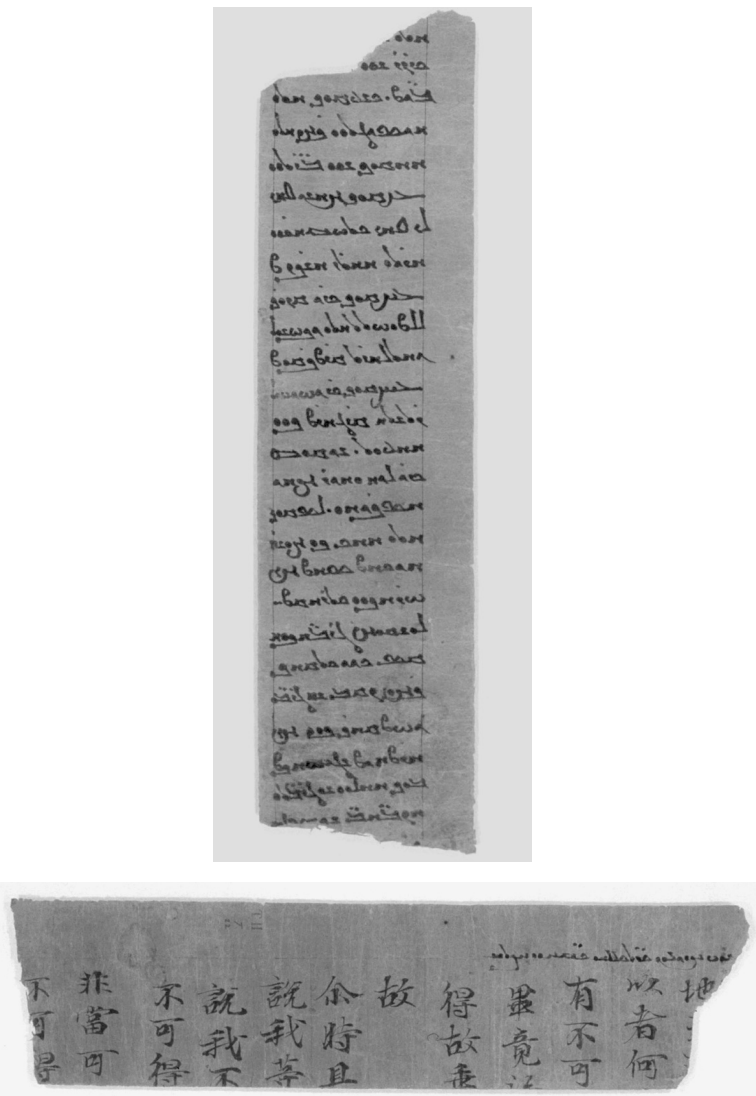

P1. 9bis.

M7420 [T II T 22]

Depositum der Berlin-Brandenburgischen Akademie der Wissenschaften in der Staatsbibliothek zu Berlin - Preußischer Kulturbesitz, Orientabteilung. Photo: Fotostelle der Staatsbibliothek zu Berlin. 


\section{B Languages}

\section{B.I. One language}

Even if most of the Sogdian fragments written in Manichaean script containing Sogdian text are monolingual, we also find bilingual and trilingual texts. A valid explanation of these "polylingual" texts is given by (HENNING 1937, 14): Persian, the language in which Mani also wrote, is the holy language of the Manichaeans in Turkestan, beside it is the Parthian language, in which Mani's Apostles had preached their religion East of Iran. The colloquial language of the Manichaeans in Turkestan, insofar as they were Iranians, was Sogdian. The uneducated Electi, and, of course, the Auditors generally only understood Sogdian; the majority of the Manichaeans in Turkestan consisted of Sogdians. In one case the Sogdian text has notes, or words written between lines or on margin. Among bilingual texts there are quite a few fragments of West Middle Iranian/Sogdian glossaries. In some cases we have examples of Sogdian/Uygur glossaries. Some texts are really bilingual, having verses of hymns in the original, interlined with their Sogdian translation. The Manichaean Bet- und Beichtbuch (BBB) has parts written in Middle Persian, Parthian and Sogdian.

\section{B.I.1}

M3611+M1134 [pl. 10]

Sogd., Uyg. Ruled margins. Tale. Publ. MoRANO 2009, 187-188. $16.4 \times 11.8 \mathrm{~cm}$. 


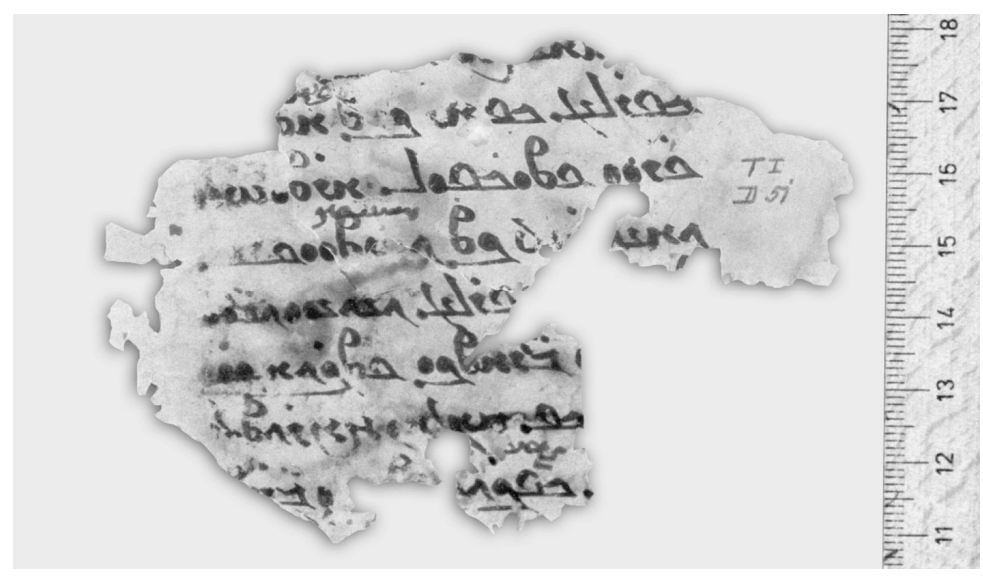

P1. 10.

\section{M3611+M1134/V/}

Depositum der Berlin-Brandenburgischen Akademie der Wissenschaften in der Staatsbibliothek zu Berlin — Preußischer Kulturbesitz, Orientabteilung. Photo: Fotostelle der Staatsbibliothek zu Berlin.

This text, and other fragments from the same manuscript (see above A.I.4 with pl. 6), has some Uygur glosses, or rather words translating the Sogdian written between the lines or on margin.

\section{B.II. Two languages}

\section{B.II.1}

Two or more languages and scripts

M6610 [pl. 11]

/A/ Sogd. in Man. script and Uyg. in Uyg. script interlined; /B/ alternate Uyg. words in Uyg. script and Sogdian words in Manichaean script. Contents: /A/ Two texts unrelated to one another written interlined; /B/ Sogdian/Uygur glossary.

This fragment holds on its two sides three different texts in two different languages: side /A/ contains two texts interlined, one in Sogdian and one in Uygur, unrelated one to the other, while side /B/ contains a Sogdian/Uygur glossary. ${ }^{18}$

${ }^{18}$ The Sogdian/Uygur glossary on side /A/ and the Uygur text on side /B/ are published in ZiEME 2011, 957-958, and the Sogdian text on side /B/ in Morano forthcoming. 


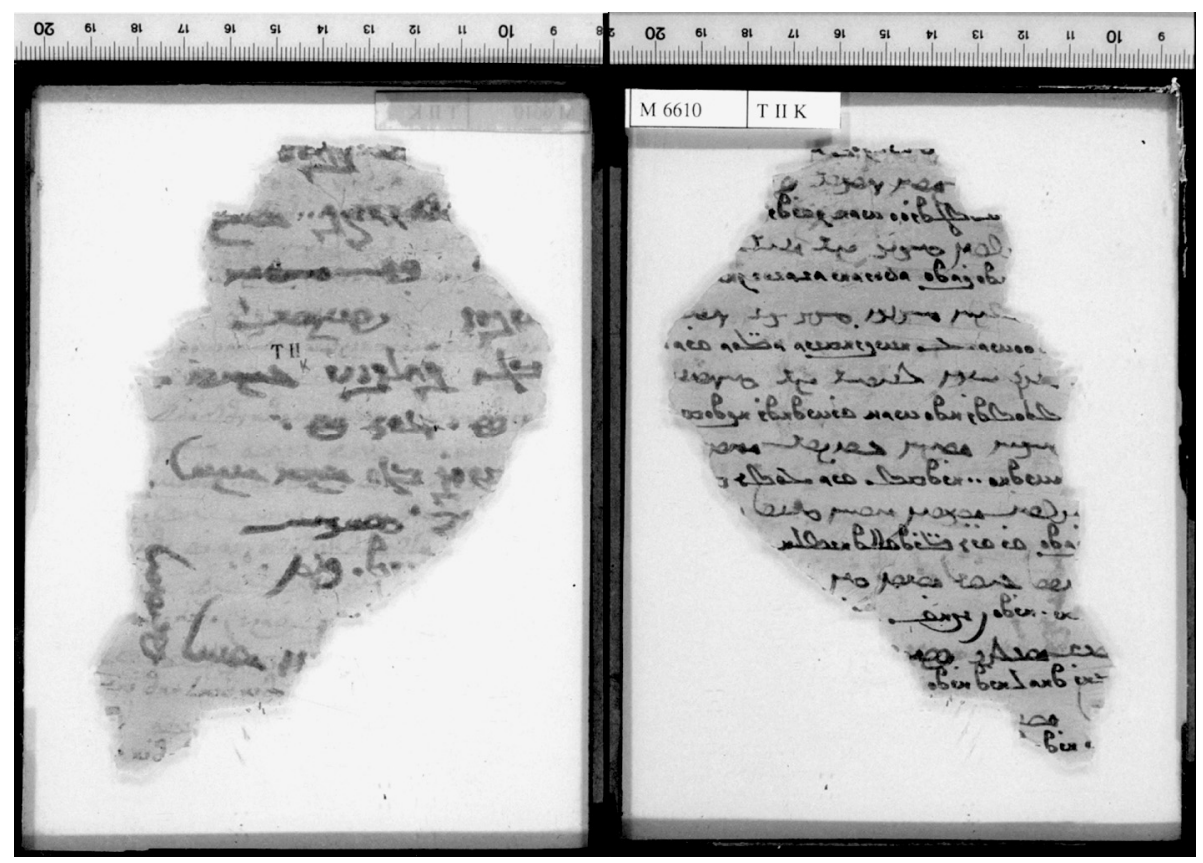

P1. 11.

\section{M6610}

Depositum der Berlin-Brandenburgischen Akademie der Wissenschaften in der Staatsbibliothek zu Berlin — Preußischer Kulturbesitz, Orientabteilung.

Photo: Fotostelle der Staatsbibliothek zu Berlin.

\section{M6610/B/}

Sogdian/Uygur glossary:

-rynčk 'boy/son' - ogl[an] 'son'

$\bullet[\ldots]-\mathbf{b}(\ddot{a}) \mathbf{k}$ katıg 'tight and hard'

$\bullet z^{\prime}$ ']wrkyn 'powerful' — küičlüg 'powerful'

•xw $\delta k$ 'r 'alone' — yalguz 'alone'

•[...] - bo 'this'

- 'yn 'this' — bo 'this'

- $m z y x \beta \gamma w$ 'Great Lord' - ulug elig 'Great King'

- $y \underline{h}$ - tugmak 'birth'

- Irt '?' - pyt '?'

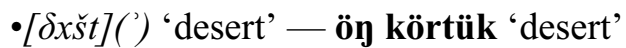




\section{B.II.2}

Three languages: Middle Persian, Sogdian and Uygur names and titles.

M640 [pl. 12]

Middle Persian, Sogd. caption, Uyg. names and titles.

Upper part of a sheet with headlines (red on the recto and blue on the verso) and rosettes. Middle Persian hymns to the Third Messenger ( $m h r^{\prime} n$ ' $y$ zyn'rys), Sogd. capt., Uyg. names and titles. $6.1 \times 9.4 \mathrm{~cm} .{ }^{19}$

The fragment contains quotations of the first lines of Middle Persian hymns with Sogdian captions indicating tune and dedication to Uygur dignitaries.
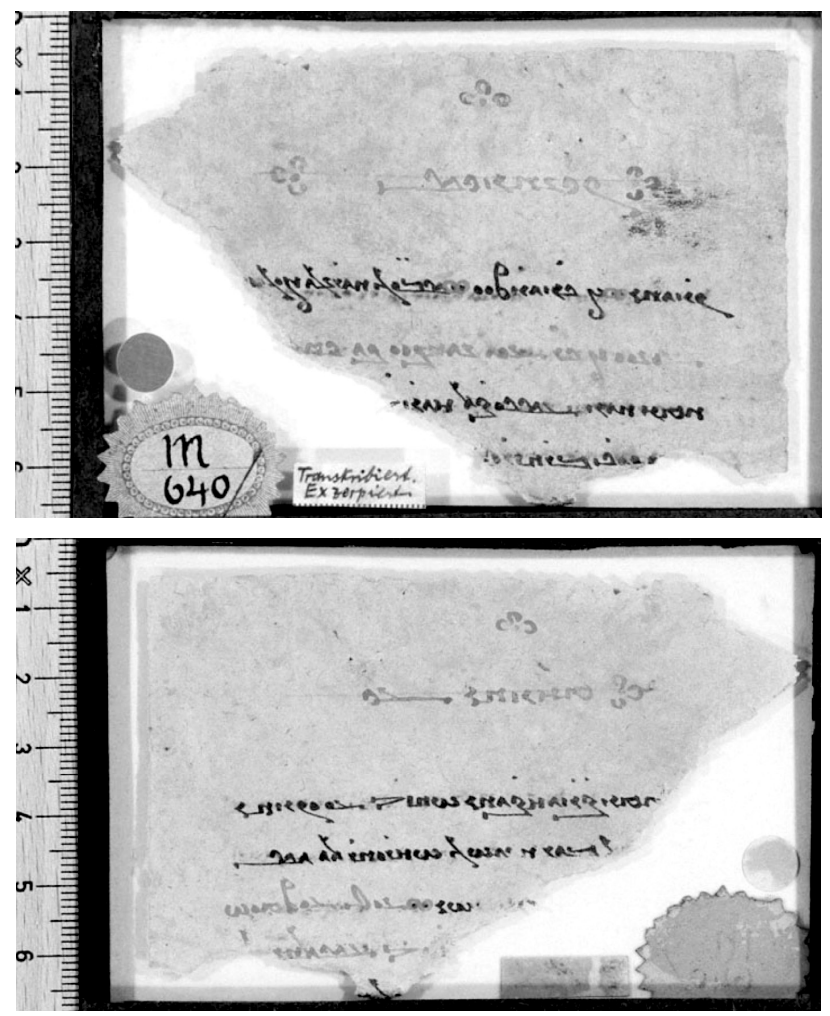

Pl. 12.

\section{M640}

Depositum der Berlin-Brandenburgischen Akademie der Wissenschaften in der Staatsbibliothek zu Berlin - Preußischer Kulturbesitz, Orientabteilung. Photo: Fotostelle der Staatsbibliothek zu Berlin.

\footnotetext{
${ }^{19}$ Publ. Durkin-Meisterernst 2014, 32; re-published with emendations in MORANO forthcoming.
} 


\section{B.II.3}

Bilingual texts: Middle Persian hymns with Sogdian translation strophe by strophe.

M776 [pl. 13]

Lines in Middle Persian followed by the Sogdian translation. Antiphonal Body-Soul hymn, same text as M114/II/ (Middle Persian). Ruled margins and horizontal grid-lines. Red captions. On /R/: "Body's speech" (tmb'ry $p t s ̌ k w ' n) .8 .6 \times 9.1 \mathrm{~cm}$.

This interesting, almost complete page contains one of the few real bilingual texts, with verses of a Middle Persian Body-Soul antiphonal hymn followed by the Sogdian translation. Rubrics indicate the words of the Soul and the replies of the Body. ${ }^{20}$
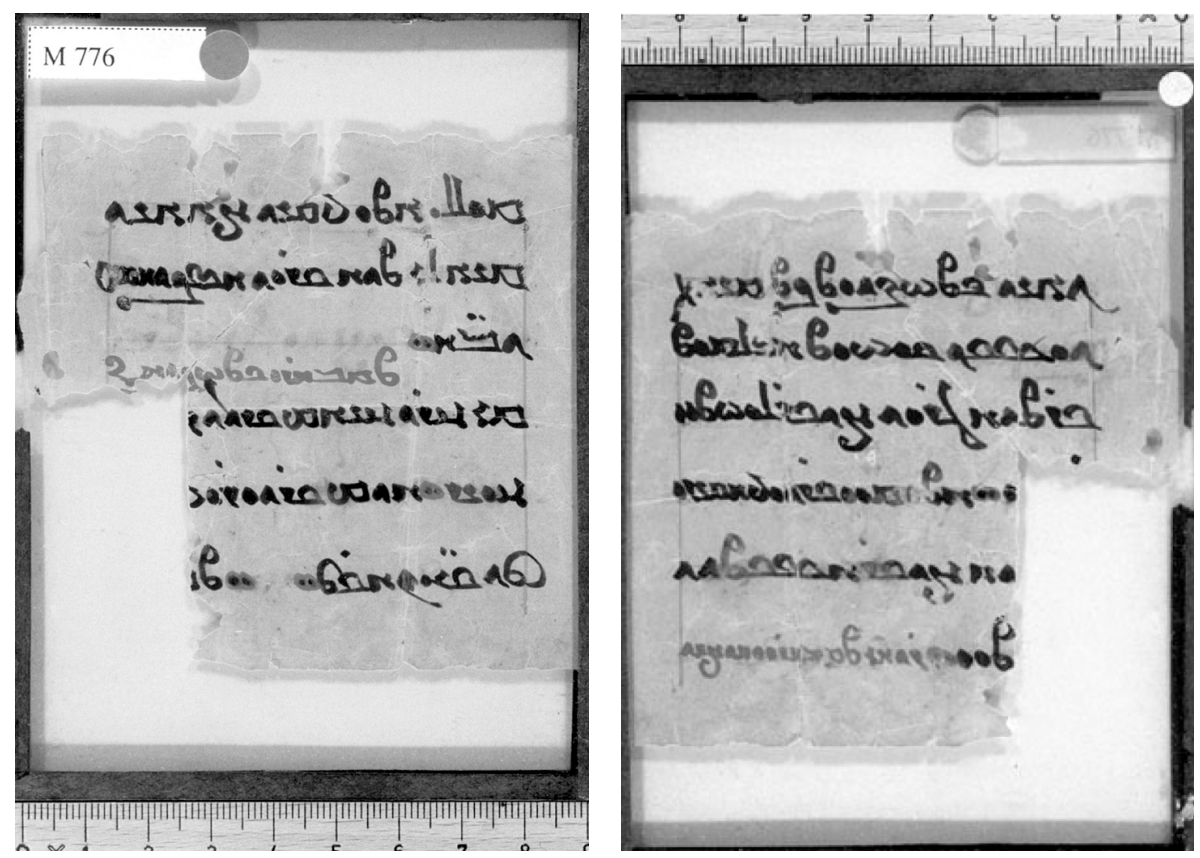

Pl. 13.

M776

Depositum der Berlin-Brandenburgischen Akademie der Wissenschaften in der Staatsbibliothek zu Berlin - Preußischer Kulturbesitz, Orientabteilung. Photo: Fotostelle der Staatsbibliothek zu Berlin.

${ }^{20}$ The remnants of the Body-Soul hymn in Middle Persian, Parthian and Sogdian are reconstructed in MORANO 2017c. 


\section{Script}

The Manichaean script, being by its nature a kind of "block script", almost without ligatures, has only a few varieties. One can distinguish:

— normal script

— elegant semi-cursive script

- cursive bold

- cursive script

- ornamental script, used in headlines with a variety

— with calligraphically elaborated "rope" letters

\section{C.I}

Normal script

Each letter is written as if it were separated from one another, with no ligatures. The ductus is rather uniform and the upward and downward strokes are thick.

\section{M548+M704}

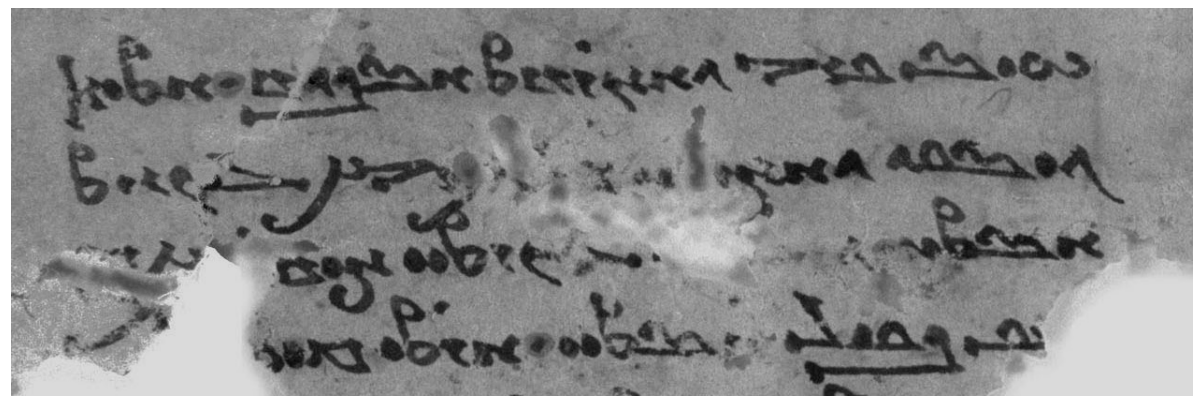

\section{C.II}

Elegant semi-cursive script

In some documents, mostly private letters, the script tends to be somehow more cursive. Some characters, such as $t$ and $k$ and $z$, have thinner upward or downward strokes and the letters tend to join, but without ligatures. 


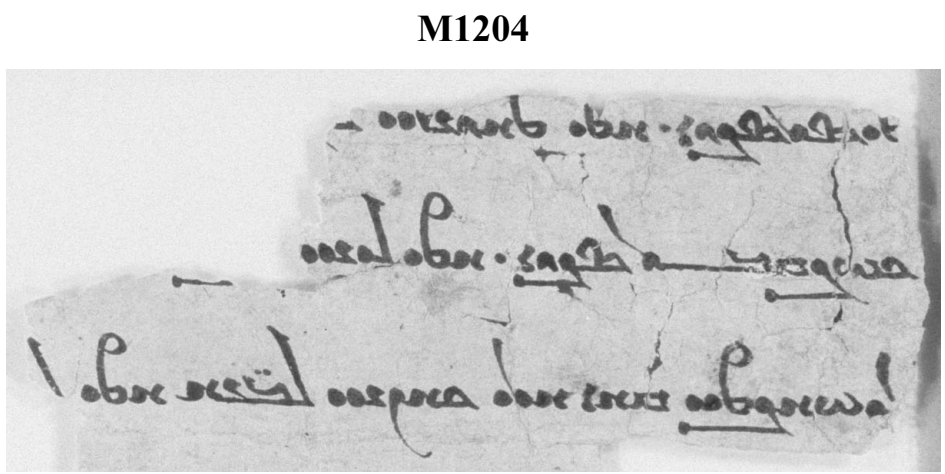

\section{C.III}

\section{Cursive bold}

A particular script style is found in a set of fragments from a manuscript containing a cosmogonical text, still unpublished. ${ }^{21}$ The characters are thick, i.e. bold, but the form of some letters, such as $t,{ }^{\prime}, s$ and $w$ are very similar to the proper cursive (see below) used in private letters.

\section{M141+M6795}

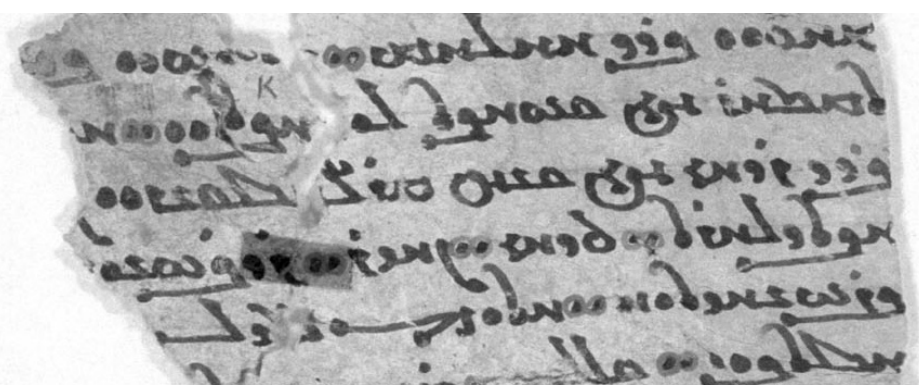

\section{C.IV}

Cursive script. ${ }^{22}$

This script style, defined by Boyce as "fine spidery late hand", ${ }^{23}$ is used mostly in private letters. The characters are very thin and are frequently

\footnotetext{
${ }^{21}$ A publication of these very interesting texts is in preparation.

${ }^{22}$ For a detailed description of this type of script, see BENKATO 2016, $212 \mathrm{ff}$.

${ }^{23}$ BoyCE 1960, 32, on M483. There is no reason for accepting the definition "late" for this type of script. See BENKATO 2016, 199 and 216-217.
} 
joined together. The shape, particularly of some letters such as ', $t, k, w, r$ is definitely "cursive", probably used by learned persons to write private letters. There are few other examples for the use of this script not in letters (e.g. M127, with short tales, not given here ${ }^{24}$ ).

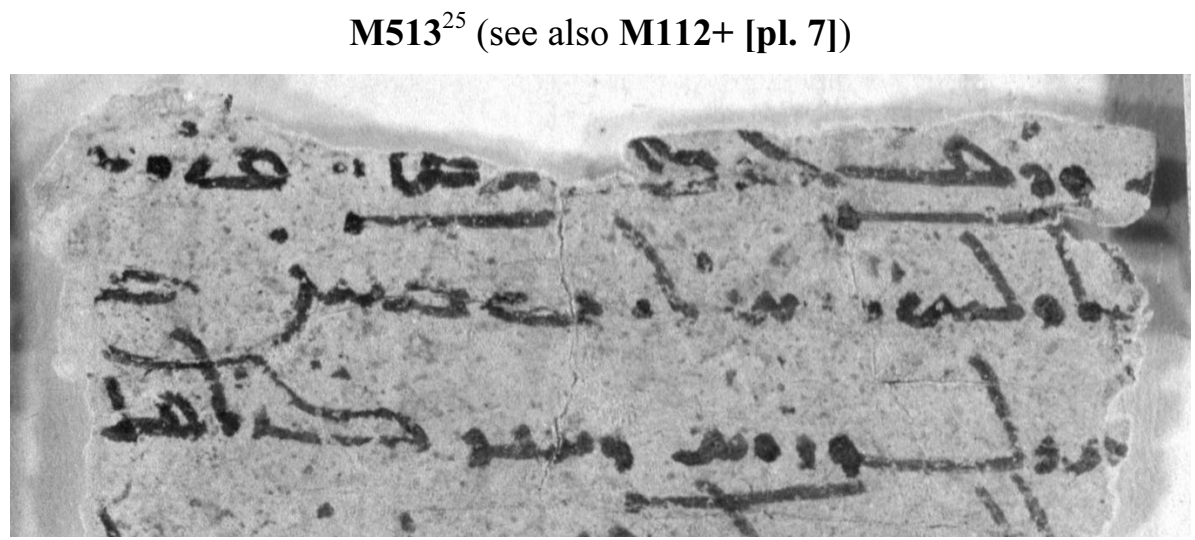

C.V-VI, see below E.I-IV

\section{Imprints}

\section{M406+M207 [pl. 14]}

/R/ Sogd., Uyg. /V/ blank. Iranian and Uyg. names $10.4 \times 12.5 \mathrm{~cm}$.

Joining the two fragments together, it is possible to reconstruct the Sogdian headline wšy' $\underline{h} n^{\prime} m(y) \underline{h}$ "Book of memory" and to understand the list of names in the text as a list of dead persons, possibly high-ranking Uygur women. ${ }^{26}$ Some lines have imprints from the previous page: at the end of the first line one can clearly see the word frnxwnd $(\beta)$ [ "glorious" mirrored from the preceding page.

\footnotetext{
${ }^{24}$ See Morano 2013, 333-334, fig. 1 and 2.

${ }^{25}$ This fragment, together with the joining M483, is published by BENKATO 2016, $204 \mathrm{ff}$.

${ }^{26}$ The text is published in MORANO forthcoming.
} 

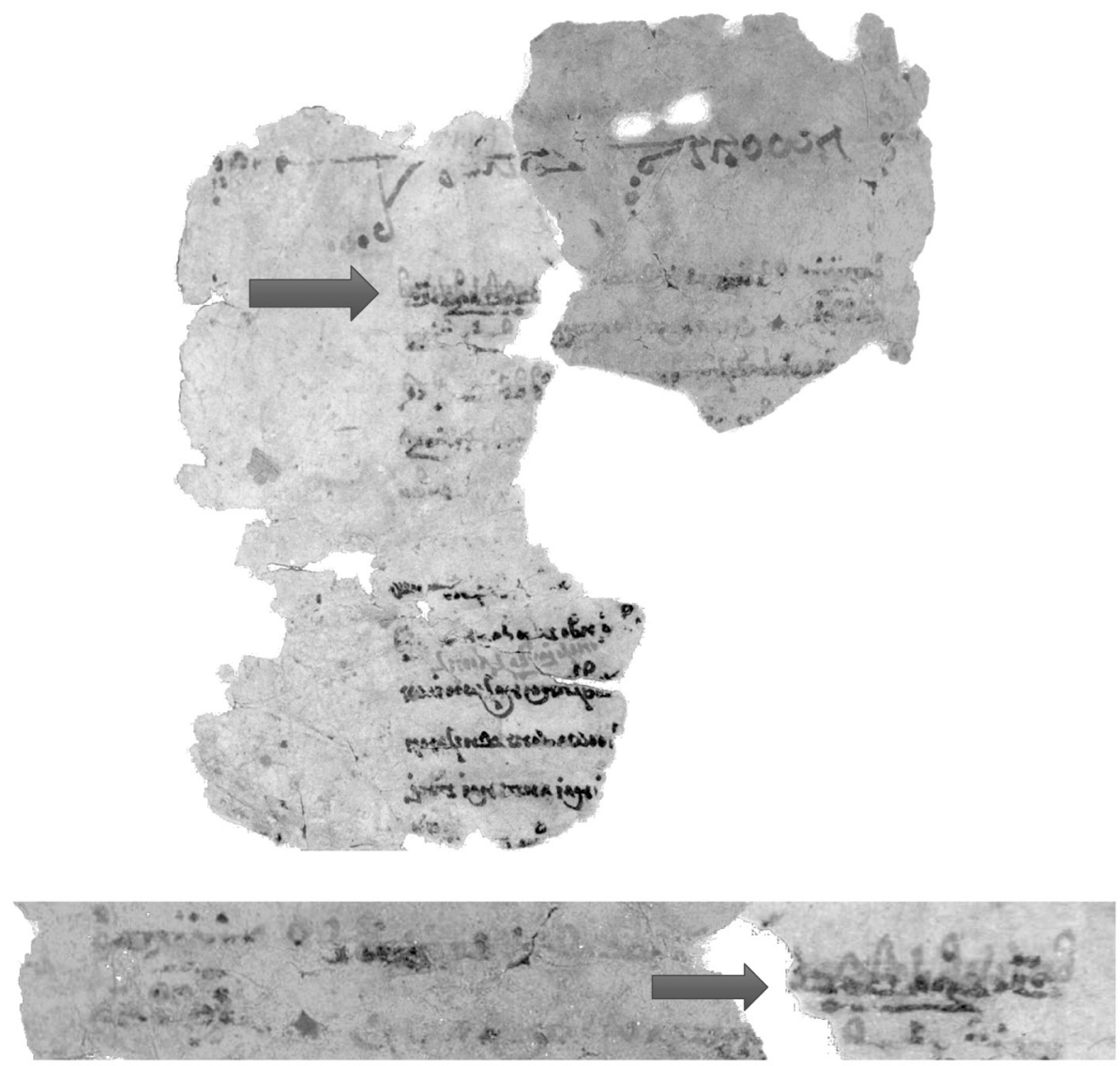

P1. 14.

M406+M207

Depositum der Berlin-Brandenburgischen Akademie der Wissenschaften in der Staatsbibliothek zu Berlin — Preußischer Kulturbesitz, Orientabteilung. Photo: Fotostelle der Staatsbibliothek zu Berlin. 


\section{E. Captions and Headlines}

The colour of the headlines varies. The most used colour for headlines is red, sometimes alternating with blue in the facing page. Red-blue rosettes encompass the headline and adorn the dots above the letters and upward and downward strokes. Captions and colophons are normally written in red ink. In the Manichaean Bet- und Beichtbuch (BBB ${ }^{27}$ headlines are written in four different colours, described in detail by Henning ${ }^{28}$ as "mennige, kobaltblau, oliv" and "karmin". This beautiful miniature book is now sealed in glass, and only one double page is visible. ${ }^{29}$ The sheets were last removed from the glass when they were photographed for publication in WEBER 2000. Unfortunately all photographs are in black and white and the colours are thus not distinguishable. A new set of colour photographs of this masterpiece is badly needed.

\section{E.I}

Simple coloured Headline

\section{M137}

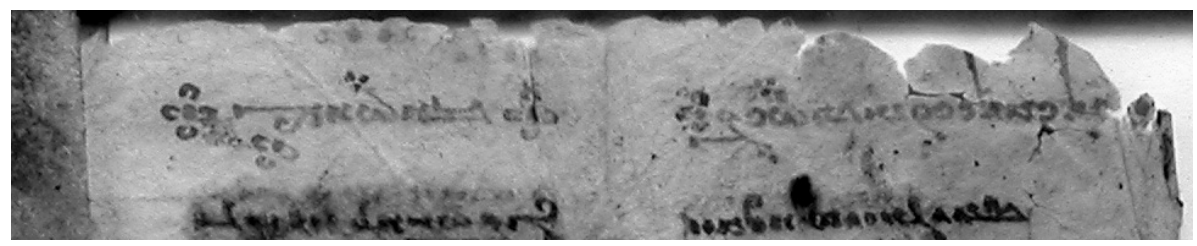

\section{E.II}

Elaborated coloured Headlines

In this magnificent example of Manichaean calligraphy two colours, dark blue and green, are used for the very fine headlines, enriched by particularly developed initials and by monochrome rosettes. The first two lines of each page are written in red ink.

\footnotetext{
${ }^{27}$ See above A.I and pl. 1.

${ }^{28}$ HENNING 1936, 4-5.

${ }^{29}$ See here pl. 1.
} 
M178 (on white leather, see above A.I.2)

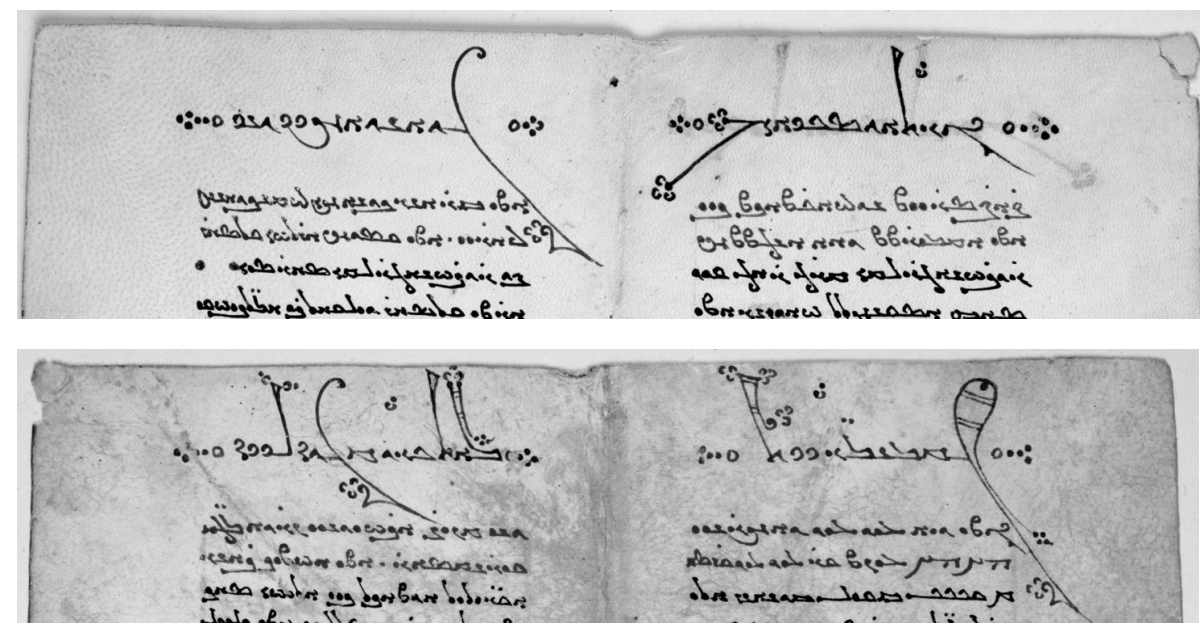

\section{E.III}

Headline with calligraphically elaborated "rope" letters

This kind of contour-defined lines, which create a three-dimensional effect like the rounded surface of a rope, is described in detail by GULÁCSI $2005,99$.

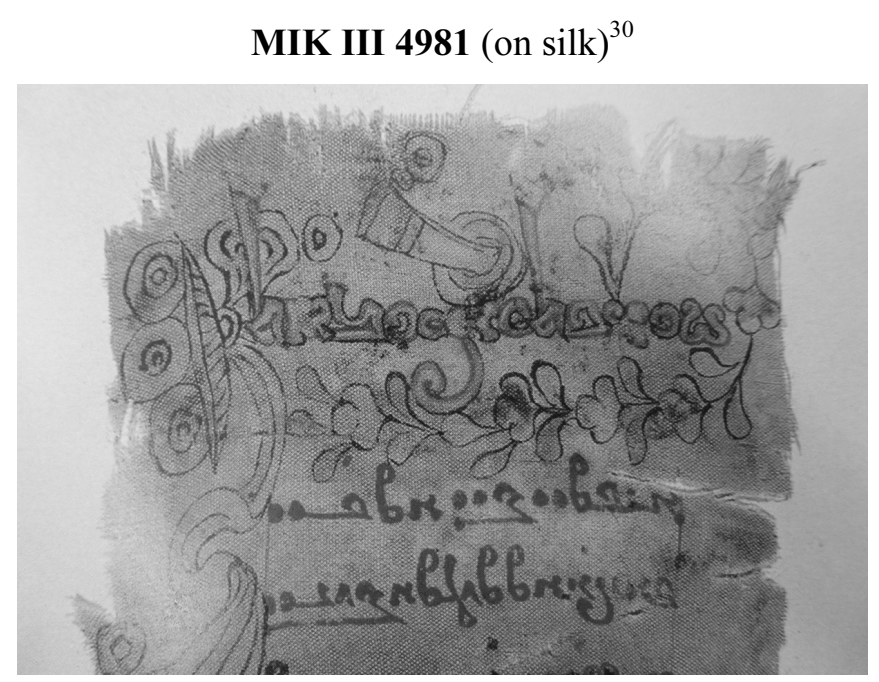

${ }^{30}$ A few codex fragments on silk were found in the Turfan area, see GULÁCSI 2005, 20 and 25 with footnote 31 . 


\section{E.IV}

Unfinished headline with calligraphically elaborated "rope" letters (M548+M704)

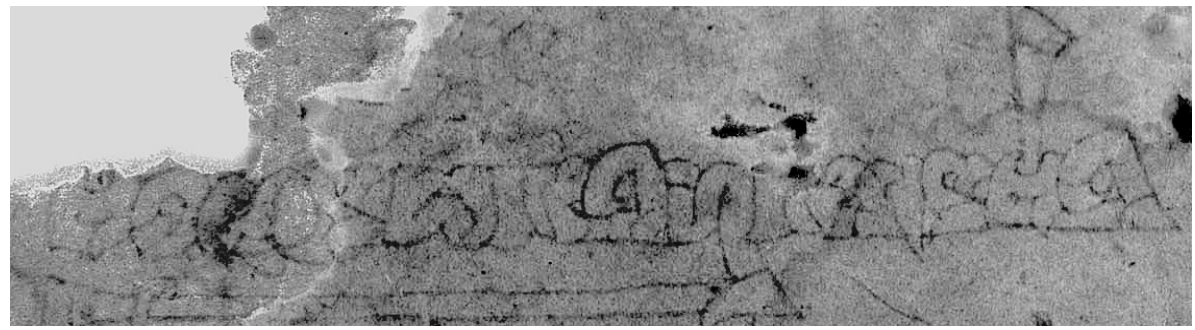

In this case the elaborated headline looks like a kind of sinoper, waiting to be filled in with colours, like the one on M171. ${ }^{31}$ It is remarkable how the "overlapping components of certain letters introduce an additional way to create the impression that some parts of the letters are closer to the viewer than others". ${ }^{32}$ These two fragments, still unpublished, were joined by me and will be edited in MORANO forthcoming 2.

\section{Abbreviations}

$\mathrm{BBB}=$ Henning 1936

Pl. = Plate

\section{References}

Benkato, Adam 2016: "Sogdian Letter fragments in Manichaean script". Studia Iranica 45, 197-220.

BenKato, Adam 2017: Āzandnāmē: An edition and literary-critical study of the ManichaeanSogdian Parable-Book (Beiträge zur Iranistik 42). Wiesbaden.

Boyce, Mary 1960: A Catalogue of the Iranian Manuscript in Manichaean Script in the German Turfan Collection, Berlin.

DuRKIN-Meisterernst, Desmond 2008: "Aspects of the organization of Manichaean books in Central Asia". Gazette du livre médiéval, no 52-53: 1-15.

Durkin-Meisterernst, Desmond 2014: Miscellaneous Hymns. Middle Persian and Parthian hymns in the Turfan Collection [Berliner Turfantexte 31], Turnhout.

Gulácsi, Zsuzsanna 2005: Mediaeval Manichaean Book Art. A Codicological Study of Iranian and Turkic Illuminated Book Fragments from 8th-11th Century East Central Asia, Leiden-Boston.

\footnotetext{
${ }^{31}$ See Gulácsi 2005, 139, fig. b.

${ }^{32}$ GULÁCSI 2005, 99.
} 
HeNNING, Walter B. 1936: Ein Manichäisches Bet- un.d Beichtbuch, Abhandlungen der Preussischen Akademie der Wissenschaften 1936, 10, Berlin [1937] [= Henning, Selected Papers I, 417-558].

HenNing, Walter B. 1940: Sogdica, London [= Henning, Selected Papers II, 1-68].

HenNING, Walter B. 1945: "Sogdian Tales". Bulletin of the School of Oriental and African Studies 11/3, 465-487 [= Henning, Selected Papers II, 169-192].

HENNING, Walter B. 1947-48: "A Sogdian Fragment of the Manichaean Cosmogony". Bulletin of the School of Oriental and African Studies, 12, 306-318 [= Henning, Selected Papers II: 301-313].

Henning, Walter B. 1977: Selected Papers I-II, Acta Iranica 15, 2ème série, Hommages et Opera Minora, Téhéran-Liège.

MorANO, Enrico 2007: "A working Catalogue of the Berlin Sogdian Fragments in Manichaean Script". In Iranian Languages and Texts from Iran and Turan: Ronald E. Emmerick Memorial Volume. Ed. by Maria Macuch and Mauro Maggi and Werner Sundermann. Wiesbaden, 239-271.

Morano, Enrico 2009: "Sogdian Tales in Manichaean Script”. In Literarische Stoffe und ihre Gestaltung in mitteliranischer Zeit. Kolloquium anlässlich des 70. Geburtstages von Werner Sundermann. Ed. by Desmond Durkin-Meisterernst and Christiane Reck and Dieter Weber. Beiträge zur Iranistik 31. Wiesbaden, 173-200 + Taf. II-VI.

MORANO, Enrico 2013: "Una pagina da un libro sogdiano manicheo di storielle, parabole

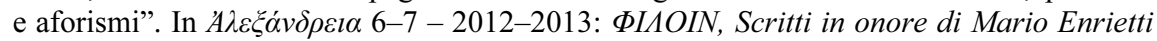
e Renato Gendre. Ed. by Mario Capaldo and Patrizia Lendinara and Mario Negri. Alessandria, 327-334.

MorANO, Enrico 2017a: "The Jackal and the Elephant: a Manichaean Sogdian Tale in Manichaean Script. With an Appendix with Corrections to Previously Edited Fragments of Tales”. In Studia Philologica Iranica. Gherardo Gnoli Memorial Volume. Ed. by Enrico Morano and Elio Provasi and Adriano V. Rossi. Serie Orientale Roma. Nuova Serie, Vol. 5, 293-298 + 3 plates.

Morano, Enrico 2017b: "Manichaean Sogdian Poems". In Manichaeism East and West. Ed. by Samuel N.C. Lieu and Erica C.D. Hunter and Enrico Morano and Nils A. Pedersen. Corpus Fontium Manichaeorum. Analecta Manichaica 1. Turnhout, 171-184 (6 plates).

MorANO, Enrico 2017c: "An Antiphonal Body and Soul Hymn in Manichaean Middle Persian, Parthian and Sogdian". In Zur lichten Heimat Studien zu Manichäismus, Iranistik und Zentralasienkunde im Gedenken an Werner Sundermann. Ed. by the team "Turfanforschung". Iranica 25. Wiesbaden, 445-452.

MORANO, Enrico forthcoming: "Uygur in the Manichaean Sogdian Texts in Manichaean Script from the Berlin Turfan Collection". Proceedings of the Symposium of SogdianTurkic Relations, November 21st-23rd 2014, İstanbul.

MORANO, Enrico forthcoming 2: "A miserable scrap". To be published in an Italian Festschrift.

MüLLER, Friedrich W.K. 1904: Handschriften-Reste in Estrangelo-Schrift aus Turfan, Chinesisch-Turkistan. II. Teil, (Anhang zu den Abhandlungen der Preußischen Akademie der Wissenschfaten 1904). Berlin.

MüLLER, Friedrich W.K. 1908: Uigurica I.2, Abhandlungen der Preußischen Akademie der Wissenschaften, Phil.-hist. Klasse, Berlin.

RECK, Christiane 2004: Gesegnet sei dieser Tag. Manichäische Festtaghymnen - Edition der mittelpersischen und parthischen Sonntags-, Montags- und Bemahymnen. Berliner Turfantexte 22. Turnhout. 
SundermanN, Werner 1980: "Probleme der Interpretation manichäisch-soghdischer Briefe". Acta Antiqua Academiae Scientiarum Hungaricae 28, 289-316. [repr. in HarmattA, János (ed.) 1984: From Hecateaus to al-Huwārizmī: Bactrian, Pahlavi, Sogdian, Persian, Sanskrit, Syriac, Arabic, Chinese, Greek, and Latin Sources for the History of Pre-Islamic Central Asia. Collection of the Sources for the History of Pre-Islamic Central Asia, 1. ser., 3, 289-316, Budapest].

SundeRmann, Werner. 1985: Ein manichäisch-soghdisches Parabelbuch. Berliner Turfantexte 15. Turnhout.

SundERMANN, Werner 2007[2008]: "Eine Re-Edition zweier manichäisch-soghdischer Briefe". In Iranian languages and texts from Iran and Turan. Ronald E. Emmerick memorial volume. Ed. by Maria Macuch and Mauro Maggi and Werner Sundermann. Wiesbaden, 403-421.

Weber, Dieter (ed.) 2000: Iranian Manichaean Turfan Texts in Publications since 1934. Photo Edition, published on behalf of the Corpus Inscriptionum Iranicarum by the School of Oriental and African Studies. Corpus Inscriptionum Iranicarum, Supplementary Series, vol. 4. London.

WiLkENS, Jens 2000: Manichäisch-türkische Texte der Berliner Turfansammlung. Verzeichnis der orientalischen Handschriften in Deutschland; Bd. 13,16. Teil 8. Stuttgart.

ZIEME, Peter 2011: "Ein Fragment einer sogdisch-altuigurischen Wortliste" / "Sogdca-eski uygurca bïr kelïme lïstesïnde artakalmiş bïr parça". In Orhon Yazıtlarının Bulunuşundan 120 Yll Sonra Türklük Bilimi ve 21. Yüzyll” konulu III. Uluslararası Türkiyat Araştırmaları Sempozyumu 26-29 Mayıs 2010, Bildiriler Kitabı. Ed. by Ü. Ç. Şavk. Ankara, 955-962. 